\title{
AMER1 Gene
}

National Cancer Institute

\section{Source}

National Cancer Institute. AMER1 Gene. NCI Thesaurus. Code C68718.

This gene may play a role in kidney development. 